\title{
Rupture zones of great earthquakes in the Himalayan region
}

\author{
PETER MOLNAR and M R PANDEY* \\ Department of Earth, Atmospheric and Planetary Sciences, Massachusetts Institute of \\ Technology, Cambridge, MA 02139, USA \\ * Department of Mines and Geology, Ministry of Industry, His Majesty's Government of \\ Nepal, Kathmandu, Nepal

\begin{abstract}
The four major earthquakes that have occurred in the Himalayan region since 1897 seem to have ruptured as little as about $15 \%$ or $20 \%$ to perhaps as much as $45 \%$ of the thrust zone separating the underthrusting Indian Shield and the overthrusting Himalayan crystalline nappes. Because of various difficulties in estimating the rupture zones for each of these earthquakes, we cannot place a tight constraint on the fraction of the Himalayan belt for which the risk of an imminent great earthquake is high. If a slip between the Indian Shield and the Himalayan crystalline nappes occurs largely by slip associated with major earthquakes, then recurrence intervals of such earthquakes are likely to be between 200 and 500 years, with a likely value of 300 years.
\end{abstract}

Keywords Rupture zone; earthquakes; Himalaya.

\section{Introduction}

Four great earthquakes have occurred in the Himalayan region in the last 100 years. The 1897 Assam earthquake seems to have ruptured a gently dipping plane beneath the Shillong Plateau (Oldham 1899; Seeber and Armbruster 1981; Molnar 1987b), and the rupture may have extended north beneath the Himalaya. The earthquakes of 1905 , 1934 and 1950 occurred within the Himalaya, and were responsible for extensive damage along the Himalaya in zones up to $300 \mathrm{~km}$ in length. Earthquakes of this type almost surely constitute the most serious seismic hazard to the residents of the Himalaya and the neighbourhood.

Several aspects of the structure and tectonics suggest that major earthquakes in the Himalaya occur as the Indian shield is thrust beneath the Himalaya (Seeber and Armbruster 1981). Fault plane solutions of nearly all moderate earthquakes $(5 \cdot 5 \leqslant M \leqslant 7)$ in the Himalaya indicate thrust faulting with one nodal plane dipping gently north or northeast and with the other nodal plane striking parallel to the range and dipping steeply south or southwest (figure 1) (e.g. Fitch 1970; Rastogi 1974; Molnar et al 1973, 1977; Chandra 1978; Baranowski et al 1984; Ni and Barazangi 1984). The gently northward or northeastward dipping planes almost surely are the fault planes. Focal depths of about $15 \mathrm{~km}$ for these earthquakes are consistent with their occurring on the top surface of the Indian shield as it underthrusts the Himalaya (e.g. Molnar and Chen 1982; Baranowski et al 1984; Ni and Barazangi 1984). Gravity anomalies over the Indo-Gangetic Plains and the Himalaya are consistent with the Indian plate extending intact northward from the Indo-Gangetic Plains approximately $100 \mathrm{~km}$ beneath the Himalaya and being flexed down as an effectively elastic plate (Lyon-Caen and Moinar 1983, 1985). Finally, the geomorphology of the 

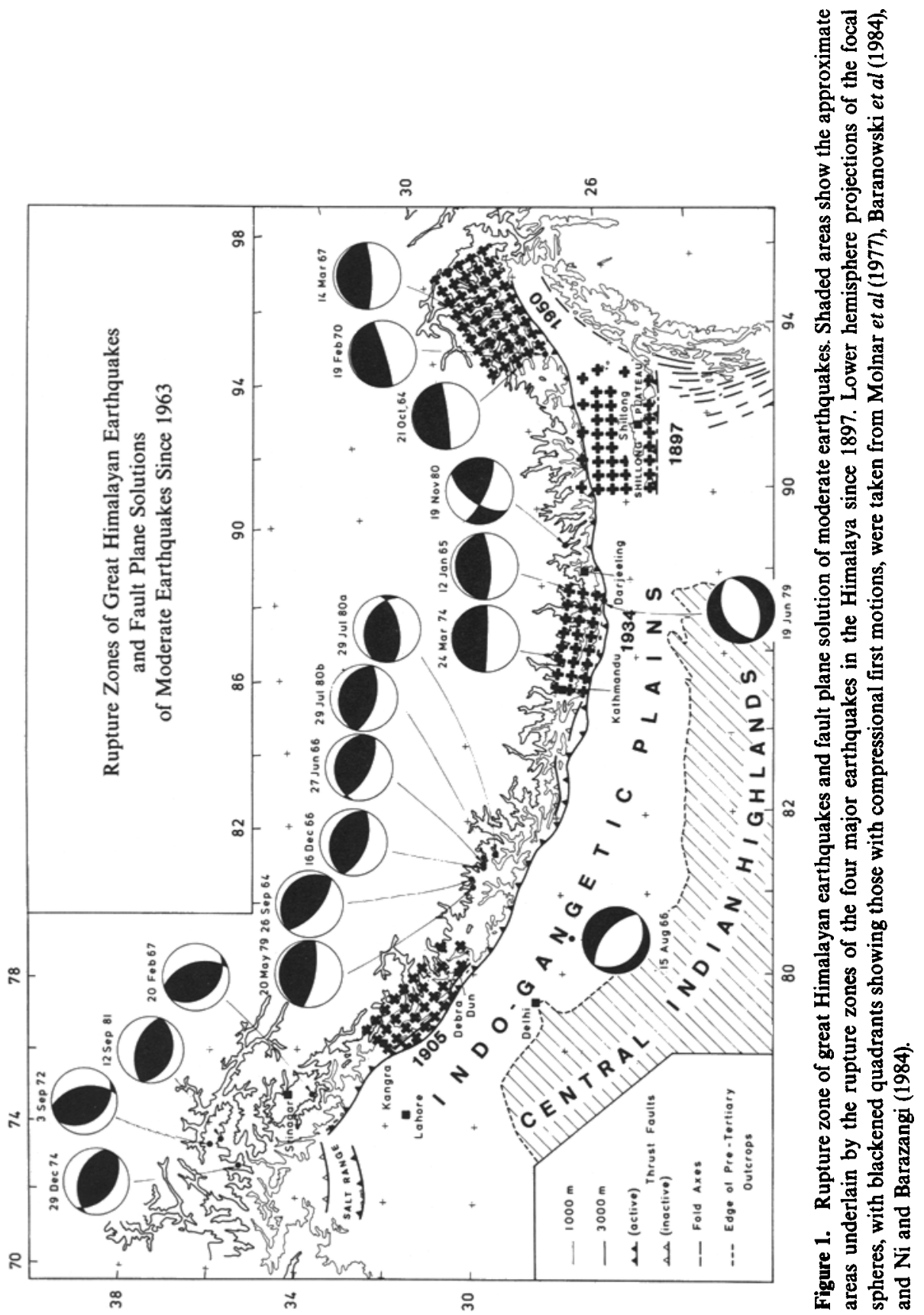
Himalaya, with an abrupt increase in elevation along the southern margin of the range, the mature landscape of the Lesser Himalaya, and the sharp incision of the Greater Himalaya, is consistent with the Indian plate underthrusting the Lesser Himalaya along a gentle plane that becomes steeper beneath the Greater Himalaya (Molnar 1987c). Thus, several observations suggest that the Indian shield is being underthrust coherently beneath the Lesser Himalaya along a gently dipping fault that steepens northward.

None of the four great earthquakes seems to be associated with primary surface faulting, and therefore the types of faults that ruptured cannot be proven definitively. Seeber and Armbruster (1981) suggested that the great Himalayan earthquakes occurred on a gently dipping thrust fault that underlies the entire Himalaya and part of the Indo-Gangetic Plains. We proceed with the assumption that this contention is basically correct, but we disagree with their estimates of the dimensions of the rupture zones, and in particular, with their inference that the ruptures extend beneath the Indo-Gangetic Plains.

We review briefly the constraints on the rupture zones of the four great Himalayan earthquakes of $1897,1905,1934$ and 1950, and we also report some tentative implications for recurrence intervals of great earthquakes in the Himalayan region.

\section{Rupture zones of great Himalayan earthquakes}

\subsection{The 1897 Assam earthquake}

Virtually everything that is known about the effects of this earthquake is given in Oldham's (1899) report. Later, others have extracted factual material to draw conclusions about the style and extent of faulting associated with that earthquake (e.g. Richter 1958; Seeber and Armbruster 1981; Molnar 1987b).

Very high accelerations and particularly great destruction were noted at numerous localities on the Shillong Plateau, and there seems little doubt that the plateau is close to the rupture zone. Indisputable evidence of surface faulting was found only on the Shillong Plateau, but the short segments and varying orientations of such faults suggest that this faulting was secondary, not primary. Warping and tilting of the earth's surface, as reflected by changes in drainage indicated important strains associated with the earthquake. Finally, a nearly continuous belt of landslides along the southern edge of the plateau suggested high accelerations there. Oldham (1899) inferred that a slip occurred on a thrust fault that dips gently northward from the southern edge of the Shillong Plateau, an inference that he later abandoned, but that seems reasonable (e.g. Seeber and Armbruster 1981; Molnar 1987b).

The likelihood of such a thrust fault cannot be denied, but its proof is lacking. The east-west striking Dauki fault, which bounds the southern edge of the Shillong Plateau, marks a vertical separation of the Pre-Tertiary basement of more than $10 \mathrm{~km}$ (e.g. Evans 1964; Sengupta 1966). Although Evans (1964) inferred a large component of strike-slip faulting, thrust faulting can account for most of the observations that he presented. The very large isostatic gravity anomalies of the Shillong Plateau (e.g. Verma et al 1976; Verma 1985) imply that the strength of the Indian lithosphere must support the plateau, and therefore underthrusting of the strong Indian plate beneath the Shillong Plateau seems likely. Neither the locations of microearthquakes (Khattri et al 1983; Kayal 1987) nor fault plane solutions and locations of moderate 
earthquakes (Chen and Molnar 1989) give a hint of such a fault. The five moderate earthquakes studied by Chen and Molnar (1989) occurred at depths between 25 and $50 \mathrm{~km}$, too deep to have occurred on a gently dipping plane that crops out as the Dauki fault, and four of the fault plane solutions show faulting on relatively steep places $\left(30^{\circ}-60^{\circ}\right)$. Thus, although Oldham's (1899) inference of a gently dipping plane seems reasonable, it is not proven.

The extent of the rupture remains in dispute. Damage associated with the 1897 earthquake was not confined to the Shillong Plateau. Oldham (1899) noted that much of the damage, particularly west and south of the plateau, could be associated with fissuring, and he specially noted that the soil conditions associated with and without fissures were different. Thus, he considered this damage to be due to superficial deformation and not to faulting of the underlying basement. One of us, Molnar (1987b), found his arguments convincing, but Seeber and Armbruster (1981) inferred that the rupture extended $100 \mathrm{~km}$ south and $200 \mathrm{~km}$ west of the plateau. The numerous reports of aftershocks felt on the plateau and just north of it and their paucity from areas to the south or west (Oldham 1899) also support the contention that the fault that ruptured underlies the plateau but not the idea that this rupture zone extends south and west of the plateau.

The eastern limit of the rupture is poorly defined, largely because Oldham and his deputies were unable to gather much data from that area. From the few observations Oldham (1899) reported, Molnar (1987b) inferred an east-west extent of the rupture of $200 \pm 40 \mathrm{~km}$, from the western margin of the Shillong Plateau, considerably less than the $550 \mathrm{~km}$ suggested by Seeber and Armbruster (1981).

The northern limit of the rupture is also uncertain. Reports of landslides and damage in Bhutan (Oldham 1899) allow the possibility that the rupture reached as far north as the Himalaya, as Seeber and Armbruster (1981) suggested. In any case, for evaluating earthquake hazards in the Himalaya, knowing the northward extent of the rupture is probably less important than determining the degree to which the 1897 earthquake relieved strain caused by the convergence of the Indian plate with the Himalaya. If the 1897 earthquake did relieve such strain, then obviously its occurrence must be considered in evaluating the earthquake hazard of the Himalaya. If, instead, the 1897 earthquake did not relieve such strain, and if the convergence of the Shillong Plateau with the Himalaya occurs essentially as rapidly as that between the rest of the Indian subcontinent and the Himalaya, then clearly the 1897 earthquake could be ignored in evaluating the earthquake hazard in the Himalaya. The available evidence seems to allow either possibility.

\subsection{The 1905 Kangra earthquake}

Middlemiss's (1910) report contained virtually all the published factual material concerning the macroseismic effects of this earthquake. The highest intensity, $X$ on the Rossi-Forel scale, was felt near the towns of Kangra and Dharamsala. The intensity decreased sharply to the west, with the intensity VIII and X isoseismals separated by only $15 \mathrm{~km}$. To the east, the decrease in intensity was more gradual. The intensity VIII, IX and $\mathrm{X}$ isoseismals are all aligned northwest-southwest, parallel to the trend of the range and surrounding the Main Boundary Fault, the thrust fault separating Tertiary from pre-Tertiary rock at the foot of the Himalaya. The limited number of observations northeast and immediately southeast of the $I=$ VIII isoseismal make 
defining its extent difficult, but it seems reasonable to assume that the length of the rupture parallel to the chain was at least $100 \mathrm{~km}$. We presume that the earthquake occurred by slip on a gently northeastward dipping plane, but there is no proof of this and little evidence to constrain the northeast limit of the rupture.

Damage associated with the 1905 earthquake was greater in Dehra Dun and Mussoori, about $250 \mathrm{~km}$ southeast of Kangra, than in most of the area southwest and northeast of these two towns. Accordingly, Middlemiss (1910) drew an isolated contour of intensity VIII surrounding Dehra Dun and Mussoori. This contour must close southeast of Dehra Dun, because very little damage was reported at Rishikesh, Hardwar, and neighbouring towns. Very few observations, however, define the closure to the northwest and probably are insufficient to rule out the possibility that the two separate $I=$ VIII isoseismals ought to be connected.

Relevelling in 1906 along a line across the Siwalik Hills to Dehra Dun, which had been surveyed in 1862, and its continuation to Mussoori, which had been surveyed in 1904, revealed $4 \mathrm{~cm}$ of uplift. Middlemiss (1910) and Seeber and Armbruster (1981) associated this uplift with the 1905 earthquake, but we remain unconvinced of this association. The amount of only $4 \mathrm{~cm}$ seems small to be associated with the rupture of a major earthquake. Moreover, the uplifted part lies in a topographic basin flanked by ranges that clearly have risen in late Cenozoic time. Thus ascribing the $4 \mathrm{~cm}$ of uplift to the 1905 earthquake seems to us to be risky.

The extent of the rupture is poorly defined, and several different possible rupture zones seem to be allowed (Molnar 1987a). One is that rupture occurred only beneath the area delimited by the $I=$ VIII isoseismal surrounding Kangra, Dharamsala, a zone about $100 \mathrm{~km}$ in length. A second possibility is that the two separate areas encompassed by the time $I=$ VIII isoseismals ruptured, for a total of about $200 \mathrm{~km}$ of the Himalayan front. Third, perhaps the entire zone from northwest of Kangra to southeast of Dehra Dun, $280 \mathrm{~km}$ in length, ruptured, as Seeber and Armbruster (1981) inferred. Included within the latter, two plausible rupture zones is the possibility that the slip on the southeastern part of the zone was less than that in the northwest, where the maximum intensity was greater. In evaluating the earthquake hazard, it seems reasonable to assume that only the segment approximately $100 \mathrm{~km}$ in length surrounding Kangra ruptured in 1905 , but also to consider the possibility that the entire zone $280 \mathrm{~km}$ in length ruptured.

\subsection{The 1935 Bihar-Nepal earthquake}

Although the 1934 earthquake was recorded by more than 100 seismograph stations, to the best of our knowledge, there are not enough consistent $P$ wave first motions to determine a fault plane solution. Singh and Gupta (1980) inferred from surface waves that strike-slip faulting had occurred, but they did not show their data to be inconsistent with thrust faulting. Chen and Molnar (1977) assumed thrust faulting and used the amplitude spectra of surface waves to infer a seismic moment. Because the inferred value of the moment is inversely proportional to the assumed dip for slip on gently dipping planes, however, their value is very uncertain. Most of what we know of this event derives from macroseismic observations.

Two important sources of macroseismic data were published independently and separately from one another: Dunn et al (1939) gave extensive information on the effects of the earthquake in India and along three traverses into Nepal, and Rana 
(1936) presented extensive data from the interior of Nepal. Neither Rana nor Dunn and his co-workers seem to have been aware of the others' work. Thus the agreement of the two reports concerning areas discussed by both gives credibility to the areas discussed by only one of them (Pandey and Molnar 1988).

Dunn et al (1939) reported three areas of very extensive damage to which they assigned an intensity of $I=I X$ and $X$ on the Mercalli scale: a belt along the India-Nepal border, a narrow zone along the Ganga river through Monghyr, and the Kathmandu valley in Nepal. The damage in all three areas seems to be due, at least in large part, to local site conditions. The extensive damage along the India-Nepal border is primarily due to slumping (the "slump belt"). Evidence for faulting in the basement is absent, and several observations imply that the slumping was superficial (Dunn et al 1939; Pandey and Molnar 1988). Localized high intensities had been noted at Monghyr in association with other important Himalayan earthquakes (Baird Smith 1843; Dunn et al 1939). Similarly, the contrast in damage within and surrounding the Kathmandu valley, both in 1934 and in 1833, when a smaller earthquake caused extensive damage, implies that local conditions are largely responsible for this localized damage. Moreover, a recent study of variations in earth noise in the Kathmandu valley shows marked variations that correlate with variations in damage in 1934 (Pandey, unpublished data, 1986). Thus, the areas assigned the highest intensity by Dunn et al (1939) do not seem to place useful constraints on the extent of the rupture.

Following the 1934 earthquake, JB Auden made three excursions into Nepal to evaluate the damage: one to Kathmandu, a second into the frontal range of the Himalaya in eastern Nepal, and a third, a traverse across the Lesser Himalaya of easternmost Nepal and the frontier with India to Darjeeling. Except for the Kathmandu valley, Auden saw little evidence for destruction as severe as that in the slump belt. These observations, together with an apparent mislocation of the epicenter of mainshock, led to the inference that the rupture zone underlies the slump belt in the Indo-Gangetic Plains and not the Himalaya (Dunn et al 1939; Richter 1958; Singh and Gupta 1980; Seeber and Armbruster 1981).

Ironically, Auden did not visit most of the areas of Nepal where destruction appears to have been most severe, and where it cannot be easily ascribed to local conditions. Rana (1936) reported almost complete destruction of the area north of Auden's central route and west of his eastern route, an area that includes Chen and Molnar's (1977) relocated epicenter of the 1934 earthquake. The severity of the destruction decreased eastward; Darjeeling was not affected much. To the west the level of destruction diminished more gradually to the area just south of Kathmandu, but west of Kathmandu, there was almost no destruction. Thus, the rupture zone probably underlies the Lesser Himalaya of eastern Nepal. The region of most severe destruction spans a segment parallel to the Himalaya approximately $100 \mathrm{~km}$ in length, but destruction was not negligible in the area from the eastern frontier of Nepal to just west of Kathmandu, about $300 \mathrm{~km}$ in length. Thus the length of the rupture zone is best described as $200 \pm 100 \mathrm{~km}$.

\subsection{The 1950 Assam (or Chayu) earthquake}

This earthquake occurred at the northeast end of the Himalaya; although the 
epicenter lies in China, numerous aftershocks beneath the Himalaya in eastern Assam (e.g. Chen and Molnar 1977) imply that at least part of the rupture zone underlies the Himalaya.

Tandon (1955) reported a fault plane solution with numerous compressional first motions at stations north, northwest, and northeast of the earthquake. He inferred normal faulting, either on a steeply northward or on a gently southward dipping plane. Ben-Menahem et al (1974) revised and added data and inferred a large component of right-lateral strike-slip faulting on a north-northwest trending steeply east-dipping plane. They used surface waves and the existence of scattered aftershocks south-southeast of the epicenter of the mainshock to corroborate this solution. Chen and Molnar (1977) found the $P$-wave first motions used by Ben-Menahem et al (1974) to be consistent with thrust faulting on either a gently north-northwest or a steeply south-southeast dipping plane, similar to those of moderate earthquakes (figure 1). Because of the extensive aftershock activity beneath the Himalaya and the similar solutions for nearby moderate earthquakes (figure 1), they inferred thrust faulting on the gently dipping planes. This solution, however, does not agree with Ben-Menahem et al's (1974) measured ratios of Love to Rayleigh wave amplitudes, and the possibility that two separate planes ruptured should not be overlooked (Molnar et al 1977; Molnar and Deng 1984). Finally, a re-examination of the aftershocks of the 1950 earthquake shows that if only those earthquakes recorded by more than 50 stations are considered, nearly all of the relocated aftershocks lie beneath the Himalaya in a zone extending roughly $250 \pm 50 \mathrm{~km}$ west of the epicenter of the mainshock and about $100 \mathrm{~km}$ wide (Molnar, unpublished data, 1985). Thus, we presume that rupture occurred primarily on a gently north-northeast dipping thrust fault.

The remoteness of the region affected by the 1950 earthquake prohibited a comprehensive investigation of the damage associated with it. Apparently no special investigation of the damage in the epicentral region was made. Ramachandra Rao (1953) showed several maps of intensity distributions for India, and all indicate a maximum intensity, $I=X I$ (or XII) on the Modified Mercalli scale, along the Himalaya to about $250 \mathrm{~km}$ west of the epicenter. The absence of data within the Himalaya limits the northward extent of this isoseismal. A Chinese map show these isoseismals closing just east of the epicenter (Anonymous 1979), consistent with the rupture underlying the Himalaya. Thus, given both the aftershock distribution and the isoseismals, we infer that dimensions of the rupture zone are about $250 \mathrm{~km}$ in its east-west dimension of about $100 \mathrm{~km}$ north-south.

\section{Summary and implications}

The lengths of the rupture zones parallel to the Himalaya for all four earthquakes exceed $100 \mathrm{~km}$; those for the events of 1897,1934 and 1950 probably are at least $200 \mathrm{~km}$; and all may reach $300 \mathrm{~km}$, but probably not more than that. Thus, if the slip during the 1897 Assam earthquake relieved the strain in the Himalaya and accommodated some of the convergence between India and the Himalaya, the strain along nearly half of the $2500 \mathrm{~km}$ of the Himalaya might have been relieved in the last 100 years. Alternatively, if the 1897 Assam earthquake did not relieve such strain, perhaps strain along as little as only $15-20 \%$ of the Himalaya chain was relieved. If we 
choose conservative, but probable, lengths for the ruptures of $200 \mathrm{~km}(1897), 100 \mathrm{~km}$ (1905), $200 \mathrm{~km}(1934)$, and $250 \mathrm{~km}(1950)$, then $30-35 \%$ of the Himalayan chain ruptured in the last 100 years. This large range of uncertainty $(30 \% \pm 15 \%)$ for the fraction of the chain along which strain seems to have been relieved since 1897 underscores our ignorance of the seismic hazard in the Himalaya.

If (1) the convergence of the Indian plate with respect to the Himalaya occurs largely by slip associated with great earthquakes, if (2) these four earthquakes relieved all of the strain that had accumulated since the last such earthquakes in the same areas, and if (3) the rate of 4 great earthquakes per century were representative of earthquake recurrence in the Himalayan region, then recurrence intervals should be between about 200 and 500 years, with a most probable value of 300 years. The areas most likely to rupture next are those that did not rupture in $1897,1905,1934$, or 1950 (e.g. Khattri and Tyagi 1983).

Clearly none of the three assumptions listed above are proven, and there is reason to doubt each of them. Several earthquakes with $M=7.5$ have occurred this century. They, as well as fault creep, may contribute a non-negligible fraction of the convergence. The possibility that different amounts of slip occurred on different parts of the 1905 rupture zone, and the differences in the measured seismic moments, if both very uncertain, for the 1934 and 1950 earthquakes imply that the amounts of slip associated with ruptures in different parts of the Himalaya have been different. Consequently, recurrence intervals for different segments also should be very different from one another. Finally, although major earthquakes did occur during the last century before 1897, reports of them (e.g. Baird Smith 1843; Oldham 1883; Dunn et al 1939; Seeber and Armbruster 1981) do not suggest that any was as large as those in $1897,1905,1934$, or 1950 . Thus, the last 100 years may not be representative of the seismic history of the Himalaya for the last few thousand years.

Studies of the great Himalayan earthquakes clearly are vital for evaluating the earthquake hazard, but enough remains unknown about each event that alone they do not place a tight constraint on the earthquake hazard. The value of these studies could be enhanced by a thorough study of archived historic documents that give information about earthquakes prior to 1897 .

Because the geologic record is not likely to contain a complete record of earthquakes that did not cause surface faulting, techniques of Quaternary geology may not provide tight constraints on the average recurrence intervals of earthquakes along the Himalaya. Obtaining such constraints probably will require a synthesis of geologic, geophysical, and historical data of various kinds. Among such data are those that constrain average Quaternary, Holocene, or more recent (geodetically measured) slip rates on the main active thrust fault in the Himalaya would be very important in future estimates of recurrence intervals.

\section{Acknowledgements}

This work has been supported in part by the National Aeronautical and Space Administration under Grant NAG5-795 and by the National Science Foundation under Grant 8500810-EAR. We thank L Jenatton for drafting figure 1 and D Frank for typing the manuscript. 


\section{References}

Anonymous 1979 Maps of isoseismals of Chinese earthquakes (Beijing: Seismology Publishing House)

Baird Smith R 1843 Memoir on Indian earthquakes. Part II. Historical summary of Indian earthquakes with some remarks on the general distribution of subterranean disturbing forces throughout India and its frontier countries; J. Asiatic Soc. Bengal 12 1029-1056

Baranowski J, Armbruster J, Seeber L and Moinar P 1984 Focal depths and fault plane solutions of earthquakes and active tectonics of the Himalaya; J. Geophys. Res. 89 6918-6928

Ben-Menahem A, Aboudi E and Schild R 1974 The source of the great Assam earthquake - an intraplate wedge motion; Phys. Earth Planet. Int. 9 265-269

Chandra U 1978 Seismicity, earthquake mechanisms and tectonics along the Himalayan mountain range and vicinity; Phys. Earth Planet. Int. 16 109-131

Chen W-P and Molnar P 1977 Seismic moments of major earthquakes and the average rate of slip in Central Asia; J. Geophys. Res. 82 2945-2969

Chen W-P and Molnar P 1989 Source parameters of earthquakes beneath the Shillong Plateau and the northern Indoburman ranges; J. Geophys. Res. (submitted)

Dunn J A, Auden J B, Ghosh A M N and Wadia D N 1939 The Bihar-Nepal earthquake of 1934; Geol. Surv. India Mem. 73

Evans P 1964 The tectonic framework of Assam; J. Geol. Soc. India 5 80-96

Fitch T J 1970 Earthquake mechanisms in the Himalayan, Burmese and Andaman regions and continental tectonics in Central Asia; J. Geophys. Res. 75 2699-2709

Kayal J R 1987 Microseismicity and source mechanism study: Shillong Plateau, northeast India; Bull. Seismol. Soc. Am. 77 184-194

Khattri K and Tyagi A K 1983 Seismicity patterns in the Himalayan plate boundary and identification of the areas of high seismic potential; Tectonophysics 96 281-297

Khattri K, Wyss M, Gaur V K, Saha S N and Bansal V K 1983 Local seismic activity in the region of the Assam gap, northeast India; Bull. Seismol. Soc. Am. 73 459-469

Lyon-Caen $\mathrm{H}$ and Molnar P 1983 Constraints on the structure of the Himalaya from an analysis of gravity anomalies and a flextural model of the lithosphere; J. Geophys. Res. 88 8171-8191

Lyon-Caen H and Molnar P 1985 Gravity anomalies, flexture of the Indian plate, and the structure, support and evolution of the Himalaya and Ganga basin; Tectonics 4 513-538

Middlemiss C S 1910 The Kangra earthquake of 4th April 1905; Mem. Geol. Surv. India Vol. 37, Geol. Surv. India, Calcutta (reprinted 1981)

Molnar P $1987 \mathrm{a}$ The distribution of intensity associated with the $1905 \mathrm{Kangra}$ earthquake and bounds on the extent of the rupture zone; J. Geol. Soc. India $29221-229$

Molnar P 1987b The distribution of intensity associated with the great 1897 Assam earthquake and bounds on the extent of the rupture zone; J. Geol. Soc. India 30 13-27

Molnar P 1987c Inversion of profiles of uplift rates for the geometry of dip-slip faults at depth, with examples from the Alps and the Himalaya; Ann. Geophiscae $5663-670$

Molnar P and Chen W-P 1982 Seismicity and mountain building. In Mountain building processes (ed.) K Hsu (London: Academic Press)

Molnar P and Deng Qidong 1984 Faulting associated with large earthquakes and the average rate of deformation in central and eastern Asia; J. Geophys. Res. $896203-6227$

Molnar P, Fitch T J and Wu F T 1973 Fault plane solutions of shallow earthquakes and contemporary tectonics of Asia; Earth Planet. Sci. Lett. 16 101-112

Molnar P, Chen W-P, Fitch T J, Tapponnier P, Warsi W E K and Wu F T 1977 Structure and tectonics of the Himalaya: A brief summary of relevant geophysical observations. In Himalaya: Sciences de la Terre (Paris: Centre National de la Recheche Scientifique) pp. 269-294

Ni J and Barazangi M 1984 Seismotectonics of the Himalayan collision zone; geometry of the underthrusting Indian plate beneath the Himalaya; J. Geophys. Res. 89 1147-1163

Oldham T 1883 A catalogue of Indian earthquakes from the earliest time to the end of $1869 \mathrm{AD} ; \mathrm{Mem}$. Geol. Surv. India 163-215

Oldham R D 1899 Report on the great earthquake of 12th June 1897; Mem. Geol. Surv. India Vol. 29, Geol. Surv. India, Calcutta (reprinted 1981)

Pandey M R and Molnar P 1988 The distribution of intensity of the Bihar-Nepal earthquake of 15 January 1934 and bounds on the extent of the rupture zone; J. Geol. Soc. Nepal 5 22-44 
Ramachandra Rao M B 1953 A compilation of papers on the Assam earthquake of August 15, 1950. Publ. No. 1, The Central Board of Geophysics, Govt. of India p. 112

Rana J B (Maj. Gen. Brahma Sumsher) 1935 Nepalko maha Bhukampa (The great earthquake of Nepal) (published in Nepali by the author in Kathmandu)

Rastogi B K 1974 Earthquake mechanisms and plate tectonics in the Himalayan region; Tectonophysics 21 47-56

Richter C F 1958 Elementary seismology (San Francisco: W H Freeman) p. 768

Seeber $\mathrm{L}$ and Armbruster J 1981 Great detachment earthquakes along the Himalayan arc and long-term forecasts. In Earthquake prediction: An international review (eds) D W Simpson and P G Richards (Washington DC: Am. Geophys. Union) Maurice Ewing Series 4, pp. 259-277

Sengupta S 1966 Geological and geophysical studies in the western part of Bengal basin, India; Am. Assoc. Petrol. Geol. 50 1001-1017

Singh D D and Gupta H K 1980 Source dynamics of two great earthquakes of the Indian subcontinent: The Bihar-Nepal earthquake of January 15, 1934 and the Quetta earthquake of May 30, 1935; Bull. Seismol. Soc. Am. 70 757-773

Tandon A N 1955 Direction of faulting in the great Assam earthquake of August 15, 1950; Indian J. Meteorol. Geophys. 6 61-64

Verma R K 1985 Gravity, seismicity and tectonics of the Indian Peninsula and the Himalayas (Hingham, Massachusetts: D. Reidel) p. 213

Verma R K, Mukhopadhyay M and Ahluwalia M S 1976 Seismicity, gravity and tectonics of northeast India and northern Burma; Bull. Seismol. Soc. Am. 66 1683-1694 